\title{
Canaã: o horizonte racial
}

JOSÉ PAULO PAES

$\mathrm{O}$ pensamento dos séculos XVII e XVIII teve na mecânica, como se sabe, o seu modelo epistemológico por excelência. Já o século XIX, sem abrir mão inteiramente da causalidade mecanicista, voltou-se de preferência para outro modelo de explicação do mundo: o biológico. Sob o influxo do evolucionismo darwiniano, e inspirando-se nos resultados da zoologia, da botânica, da anatomia e embriologia comparadas, e da microbiologia, os teóricos desse século autodenominado da ciência extrapolaram com frequiência o molde explicativo de tais disciplinas para outros campos dela distanciados. No terreno das teorias sobre a sociedade humana, vulgarizou-se então o chamado darwinismo social, e uma de suas manifestaçōes extremas foram as teorias racistas. Elas vinham de resto ao encontro dos interesses do colonialismo europeu, sob cuja égide as noçōes de civilização e barbárie, saturadas de conteúdo ideológico, ofereciam um álibi supostamente objetivo para a fundamentação das noçōes subsidiárias de raças superiores e raças inferiores.

Empenhada como andava em sintonizar o pensamento brasileiro com a filosofia e a ciência mais avançadas de sua época, nada mais natural que a geração de 70 sofresse, em maior ou menor grau, a influência do racismo "científico." Todavia, em vez de contentar-se em copiar passivamente as categorias e postulados instrumentais do saber europeu do século XIX, alguns dos representantes e continuadores da Escola do Recife cuidaram de adaptá-los às peculiaridades de nossa realidade sócio-histórico-cultural. Sílvio Romero, por exemplo, embora se louvasse em autores como Gobineau e Oto Amon e, na esteira deles, considerasse índios e negros como "povos inferiores", do mesmo passo em que tinha o "genuíno Ariano" como "o verdadeiro autor da civilizaçáo", nem por isso deixava de chamar a atenção para a importância do "nosso mestiçamento fundamental inegável" $\mathrm{e}$ de enumerar-lhe as vantagens do ponto de vista da aclimatação ao meio, do avanço da civilização, da "possível unidade da geraçáo futura" e do desenvolvimento das "faculdades estéticas da imaginativa e do sentimento". Como dá a perceber a referência a uma "possível unidade da geração futura", idealizava Sílvio um tipo ético definido de brasileiro, a que corresponderia um caráter e uma cultura nacionais igualmente definidos. $O$ mestiçamento lhe parecia ser, não obstante suas eventuais vantagens, "uma das çausas de certa instabilidade moral na populaçáo, pela desarmonia das índoles 
e das aspiraçóes no povo, que traz a dificuldade da formação de um ideal nacional", donde ele adiar para um "futuro mais ou menos remoto" a consecução da nossa "almejada unidade" racial, que se traduziria, a seu ver, num progressivo embranquecimento da população brasileira: " será mister que se dêem poucos cruzamentos dos dois povos inferiores [os negros e os índios] entre si, produzindo-se assim a natural diminuição destes, e se dêem ao contrário, em escala cada vez maior com indivíduos da raça branca" (1).

No pensamento de Euclides da Cunha vamos encontrar a mesma confusão entre cultura e raça, típica da ciência do seu tempo. Num dos luminares desta, Gumplowitz, "o grande professor de Gratz", foi o autor de Os sertôes buscar o "belo axioma" de a luta de raças se constituir na "força motriz da história". À luz de tal axioma, vê ele também a "raça forte" esmagando sempre a "raça inferior", seja pela guerra, seja pela "sua diluiçáo no cruzamento", seja enfim pela civilizaçăo. Os mestiços the aparecem como os "mutilados inevitáveis" da luta racial: histéricos, neurastênicos, desequilibrados, seriam espíritos fulgurantes, às vezes, mas frágeis irrequietos, inconstantes" para os quais a "raça superior torna-se o objetivo remoto" a que tenderiam. O suposto desequilíbrio de caráter do mestiço, particularmente do mulato, Euclides o atribui ao choque entre a ânsia de igualar-se à raça superior $e$ a incapacidade de avir-se com "a sobrecarga intelectual e moral de uma civilizaçáo" para a qual não estaria biológica ou racialmente qualificado. Daí infere Euclides aquela que se poderia chamar de moral antropológica de Os sertôes: apesar de mestiço, o sertanejo é "antes de tudo, um forte" porque, perdido nas lonjuras do interior do País, onde ficou esquecido da sua civilização eminentemente costeira, não se viu forçado, como os "mestiços neurastênicos do litoral", a enfrentar as tensóes da "adaptaçáo penosíssima a um estádio social superior", nem tampouco a descambar nas "aberraçóes e vícios dos meios adiantados". Lá, teve tempo histórico bastante para enrijecer o organismo na "intimidade com o meio físico", criando uma "raça cruzada (...) autônoma e, de algum modo, original", vocacionada para "novos e mais altos destinos", quais sejam "alcançar a vida civilizada por isto mesmo que náo a atingiu de repente". Vida civilizada que tudo leva a crer Euclides idealizasse não como apenas a "cultura de empréstimo" com que se têm contentado os litorâneos brasileiros, "etnologicamente indefinidos, sem tradiçóes uniformes", e sim como uma cultura simetricamente "autônoma e, de algum modo, original" (2).

A mesma ordem de idéias, de indistinção entre raça e cultura(2b), ou de subordinaçăo desta àquela, é a que vamos encontrar nas páginas de Canaã, de Graça Aranha, mas não em registro monódico, como em 
Sílvio Romero e Euclides da Cunha. Por se tratar de um romance de idéias, elas ali aparecem em registro polifônico, dialeticamente contrapostas umas às outras. A defesa da causa racista fica por conta de Lenz, jovem imigrante alemão cuja figura foi talhada pelo figurino nietzschiano, e que é secundado nisso, com menor veemência, pelo brasileiro Paulo Maciel, um juiz municipal bovaristicamente inconformado com a vida de província e descrente do futuro de sua pátria. A refutação do racismo incumbe a outro imigrante alemão, Milkau, cuja voz solitária tem a vantagem de ser a do protagonista do romance e seu principal foco narrativo.

Ainda que nâo chegue a falar em termos explícitos dos arianos táo estimados por Sílvio Romero, Lenz estava pensando implicitamente neles quando, numa noite de insônia pouco depois de sua chegada ao Espírito Santo, tem uma visão dos "batalhadores eternos" da "antiga Germânia" desembarcando em terras brasileiras, "com sua áspera virgindade de bárbaros", para nelas fundar "um novo império" e as cobrir com os seus "corpos brancos" (3). A idolatria de Lenz pela "tendência imperial, a fibra belicosa, a expansão universal, a tenacidade, o gênio militar, a disciplina" dos seus compatriotas teuto-arianos se faz acompanhar, como não poderia deixar de ser, de um completo desdém pela inferioridade racial dos povos não-arianos e, principalmente, dos mestiços. No brasileiro ele về tão-só um híbrido incapaz de progresso, com o que se mistura, num mesmo estereótipo, a noçáo de progresso como fruto da capacidade genésica ou criativa do homem com a idéia subliminar de o híbrido ou mestiço humano ser pouco ou de todo infecundo, esdrúxula inferência zoológica que, louvado em Broca, Sílvio Romero parece ter também perfilhado(4). Por náo acreditar Lenz que sobre a mestiçagem ou "fusáo com espécies radicalmente incapazes (...) se possa desenvolver a civilização", tem ele como ponto pacífico que o "problema social para o progresso de uma regiáo como o Brasil, está na substituiçáo de uma raça híbrida, como a dos mulatos, por europeus"; a imigração tem para ele, portanto, menos o sentido de um encontro e interpenetração de culturas diferentes que de uma política de tábula rasa em que uma cultura superior vem erradicar totalmente uma cultura inferior para substituí-la.

No preconceito contra os mulatos incorre igualmente Paulo Maciel, o juiz municipal de Porto do Cachoeiro que, nos capítulos finais de Canaã, durante os trâmites do processo contra Maria Perutz - a suposta infanticida cujo transe se encarrega de infundir um pouco de dramaticidade nesse que José Veríssimo já incluíra na moderna "categoria dos romances sem enredo" (5) - , se torna amigo de Milkau e seu outro interlocutor, afora Lenz, em "longas e nobres" (6) palestras acerca do 
GRAÇA ARANHA

da Academia Brasileira

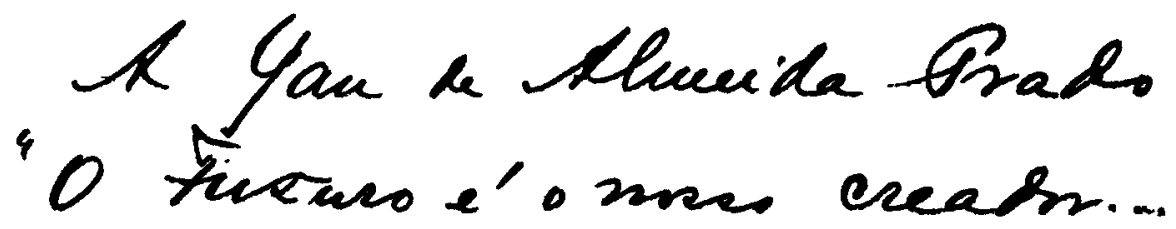

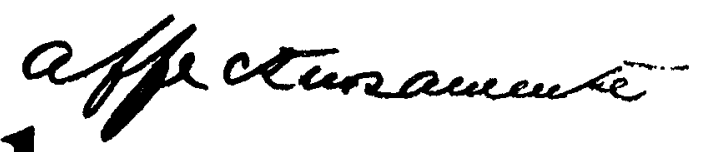

Chanaan

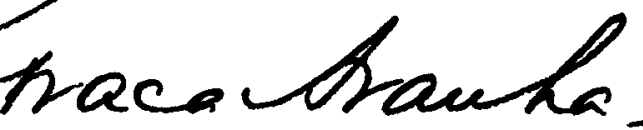

1923

H. GARNIER

LIVREIRO-EDITOR

Rio de Janeiro
Fac-stmile do

frontisplcio da 1 edifito do livro Cana 
presente e do futuro do País. Palestras nas quais se vai esboçando uma espécie de teoria do Brasil que tem como fundo de quadro permanente o horizonte racial, ou seja, a já referida indistinção entre cultura e raça que se prolongaria da Escola do Recife ao Modernismo paulista de 22-28, cujo ideário influenciou. Para Maciel, que argumenta com base na sua experiência jurídica de campo, o Brasil, onde "já houve talvez uma aparência de liberdade e de justiça", não passa "hoje" de "um cadáver que se decompóe". Tendo em vista o tempo e lugar da narrativa de Canañ, decorrida entre o ocaso do Império e os primórdios republicanos, quando se agravou ainda mais a decadência das velhas propriedades rurais do Espírito Santo que não substituíram, ou năo puderam substituir, o braço escravo pelo trabalho livre, é lícito inferir que o "já houve" se refere ao Segundo Reinado e o "hoje", aos primeiros dias da República. Sobre o cadáver do Brasil recém-republicano, Maciel vê lançarem-se os urubus do imperialismo europeu e norte-americano, contra cuja fome de conquista nada podia o arremedo de naçáo em que nos transformáramos. Tal incapacidade se devia, no seu entender, à "crise de caráter" do País, à falta de "um fundo moral comum", já que "náo há dois brasileiłos iguais", crise responsável pela nossa "inércia moral" e pelo avanço cada vez maior de "um cosmopolitanismo dissolvente" entre nós. A conclusão pessimista de Maciel reflete bem uma preocupaçáo com a decadência que era típica do Zeitgeist do fim do século em que Canara foi concebido e escrito: "A decadência aqui é um misto doloroso de selvageria dos povos que despontam para o mundo e do esgotamento das raças acabadas". Os dois termos deste binômio podem ser identificados respectivamente com os mestiços brasileiros e os brancos europeus. Levando avante uma colocaçáo de Milkau acerca do mulato, Maciel reconhecia que no Brasil era preciso mesmo "formar-se do conflito de nossas espécies humanas um tipo de mestiço, que se conformando melhor com a natureza, com o ambiente físico, e sendo a expressão das qualidades médias de todos, fosse o vencedor e eliminasse os extremos geradores". Os óbvios pontos de semelhança entre esta média racial, evolucionariamente adaptada à ambiência tropical, e o sertanejo forte $\mathbf{e}$ autônomo, idealizado por Euclides da Cunha, dispensam maiores comentários. Mas não passe sem registro que, branco de "uma inteligência mais fina, de uma sensibilidade maior e mais distinta" que the são reconhecidas por Milkau, lamenta-se Maciel ironicamente, a páginas tantas, de não ter nascido mulato, com o que seu "equilíbrio com o país seria então definitivo" e ele se alinharia entre os "donos da terra", ao lado do escrivão Pantoja e do promotor Brederodes, personificaçōes, juntamente com o juiz de direito Itapecuru, da venalidade e da prepotência do Poder público. 
Articulado em oposição ao arianismo agressivo de Lenz e ao pessimismo racial de Maciel, nem por isso o discurso de Milkau consegue ultrapassar-lhes o horizonte de preocupaçóes. A certa altura, afirma ele que a idéia de raça não passa de um "preconceito aristocrático" (7), dada a dificuldade de definir o que seja exatamente, e que tampouco existe uma "raça privilegiada" capaz de arrogar-se o papel de "agente da civilizaçáo", desempenhado já tanto pelo semita e pelo hindu antigos quanto pelo francês e pelo inglês de hoje. Esboça-se com isso uma desvinculação entre as noçóes de raça e de civilização ou cultura, mesmo que esta última, assim expressa num singular generalizador, esteja ainda longe da pluralidade e eqüiponderância de culturas táo encarecidas pelo antropólogo de nossos dias ansioso de inocentar-se do eurocentrismo de que enfermavam os seus antecessores. Náo obstante, avulta no discurso de Milkau uma recorrência ao critério de raça que lhe compromete $o$ propalado anti-racismo. Além disso, ao mesmo tempo em que afirma que as "raças civilizaram-se pela fusão", estabelece ele uma distinção entre "raças adiantadas" e "raças virgens, selvagens", atribuindo aos "povos superiores" a iniciativa do "desdobramento da cultura", da qual seriam eles supostamente os únicos criadores e promotores. Uma visáo que corresponde ao conceito linear de progresso em voga no Monismo evolucionista do século XIX, a que Graça Aranha se filiou desde os dias de acadêmico de Direito no Recife, onde foi discípulo e amigo de Tobias Barreto. Sem chegar ao encarecimento do bárbaro e do selvagem por via do qual o primitivismo modernista de 22-28 contestou a academização do critério de civilização, Canaã, confirmando o seu caráter eminentemente pré-modernista, dava um primeiro passo nesse sentido ao reconhecer a participação das "raças virgens, selvagens" no processo civilizatório, ainda que lhes atribuísse, dentro dele, um papel dependente e passivo.

Ao questionar o racismo "científico" posto em moda pela Escola do Recife, Graça Aranha, embora não conseguisse se desvencilhar da noção de raça enquanto categoria instrumental, antecipava em quatro anos o desmascaramento ideológico desse mesmo racismo por Manuel Bonfim no seu memorável e quase esquecido A América Latina (1905) (8). Entretanto, a teoria do Brasil que se esboça na discussão travada entre Maciel e Milkau, no antepenúltimo capítulo de Canaã, gira em torno do postulado de que só com base numa unidade étnica é que poderá haver uma civilização ou cultura brasileira diferenciada e una. A ausência de um "caráter de raça" ou "fundo moral comum" no Brasil, que tanto Milkau quanto Maciel deploram, é atribuída por eles a uma "profunda disparidade entre as várias camadas da população", a uma "falta de homogeneidade" pela qual explicam o "desequilíbio" e a 
"instabilidade" do temperamento nacional, termos esses que trazem logo à lembrança os mestiços litorâneos, histéricos e desequilibrados, do esquema caracterológico de Euclides da Cunha. Até este ponto, os dois interlocutores concordam entre si; daí por diante, vão discordar frontalmente. No seu pessimismo radical, Maciel não vê șalvação possível para o Brasil, que padeceria de "uma incapacidade de raça para a civilizaçáo", estando fadado a se tornar branco em breve, "quando for consquistado pelas armas da Europa". Já na visão utópica de Milkau, cujo otimismo o drama distópico de Maria Perutz conseguiu apenas abalar, mas não destruir, a crise por que o País passa tem raízes históricas "na luta de classe, de dominados contra dominadores". Felizmente para nós, porém, "a sensualidade dos conquistadores" portugueses teve o mérito involuntário de deitar abaixo "os muros da separaçăo" entre brancos, de um lado, e índios e negros de outro, para formar "essa raça intermediária de mestiços e mulatos, que é o laço, a liga nacional, e que, aumentando cada dia, foi ganhando os pontos de defesa dos seus opressores". Milkau vê culminar esse processo de gradual conquista do espaço do poder no momento em que o Exército passa a ser "dominado pelos mestiços". A revolta destes - conquanto não seja dado nome a tal revolta, é de supor se trate da República - equivaleu a uma "desforra de oprimidos" em conseqüência da qual surgiram "instituiçóes" que estavam em consonância com "os instintos psicológicos que as criaram". Assim, por via de um "choque do inconsciente", foi que se afirmou enfim "a nacionalidade".

Esta ênfase nos fatores instintivos ou inconscientes da dinâmica social merece ser sublinhada. Entre as influências que plasmaram o pensamento da Escola do Recife no geral, e a metafísica de integraçáo cósmica de Graça Aranha em particular, estava a filosofia do inconsciente de Eduard von Hartmann. Pensador de orientaçáo schopenhauriana, Hartmann fez do Inconsciente um absoluto metafísico e o pôs na origem do Ser como a um só tempo vontade irracional e idéia inconsciente; o fim para o qual se orientaria o processo cósmico seria a Idéia emancipar-se do Querer para que o dito processo pudesse tomar consciência de si e com isso autodeterminar-se. Ao condimentar o Racionalismo cientificista do século XIX com o Irracionalismo hartmanniano, o pensamento metafísico de Graça Aranha, tal como esboçado fragmentariamente em Canañ e duas décadas mais tarde sistematizado em $A$ estética da pida, reafirmava o seu caráter vincadamente pré- modernista no antecipar, de forma embrionária, um dos pontos-chave do ideário do 22-28, que privilegiou a ordem subconsciente como a ordem por excelência da criaçáo poética e fez da perquirição psicanalítica das "raízes da raça" (9) o principal meio de estabelecer contacto com "um outro Bra- 
sil de enlaces profundos, ainda incógnito, por descobrir".

Mas voltando à questão do ascenso social do mestiço até chegar ao domínio do Exército e à tomada do poder político, trata-se de uma idéia que, apenas apontada em Canaã, seria desenvolvida por Graça Aranha num dos ensaios de Espirito moderno (1925). Ali, ao discorrer sobre um dos seus temas favoritos, "Mocidade e estética" (10), refere-se ele ao

"resultado tumultuário da transformação social" que se seguiu à Abolição e à República, quando a mocidade brasileira, depois de se ter ilustrado filosoficamente no Monismo e no Positivismo dos fins do século XIX, submergiu-se na "inconsciência nacional", abrindo assim as comportas para o desencadeamento de todos "os instintos mais primitivos, todas as aspiraçōes mais grosseiras". É então que o ensaísta vê surgir a figura do "homem novo" do Brasil, por ele descrito negativamente como "o rebento da mestiçagem, a flor da plebe [que] invade a sociedade, de que os seus incertos antepassados eram excluídos". $O$ caráter desse homem supostamente novo, que se dedica as mais das vezes à politicagem rasteira, ao jornalismo venal e ao ganho fácil, é o de um "tenebroso demônio da concupiscência, do ódio e da rapacidade". Daí não estranhar mergulhasse o País numa "crise de decrepitude precoce", em que a inteligência, sob a ação dissolvente da "preguiçosa languidez tropical", definhava numa "dolorosa mistura de decrepitude e infantilidade".

Descontada a ênfase do traço, que chega a beirar a caricatura, temos aí, a par de uma imagem ferozmente crítica da República Velha, a imagem correlata e emblemática do mestiço vitorioso tal como a esboça $o$ antepenúltimo capítulo de Canaã. Imagem típica de quem olhasse o social pelo prisma do determinismo geográfico, o que é o caso por excelência da geração de 70, haja vista a noção de "estilo tropical" formulada por Araripe Júnior. Para ele, a "influência catalítica da terra" explicava o temperamento do homem dos trópicos, que "sensualiza-se até com o contato do ar" porque ali "o genesismo terrestre assume proporçóes enormes" (11). No mesmo texto, refere-se mais adiante, numa articulação causal entre o geográfico e o racial, o trópico e a mestiçagem, a " todo o sensualismo que queima os nervos do crioulo". E num outro texto, a biografia de Gregório de Matos (1894), propóe-se Araripe Júnior traçar a certa altura o que chama de psicologia dos mulatos, deles dizendo que "graças ao ódio dos reinóis, os quais os afagavam quando escravos e desprezavam quando forros, mantinham toda a dinâmica liberal daquelas regiōes", de vez que neles existiria, "como temperamento, o espírito de insurreiçáo (...) espírito de revolta, de ódio inquebrantável" (12). 
Ao temperamento insurrecional do mulato, tal como aparece no perfil psicológico dele estereotipicamente traçado por Araripe Júnior, correspondem, na descrição náo menos estereotípica de Graça Aranha, aqueles "instintos mais primitivos" e aquelas "aspirações mais grosseiras "em que se alicerçaria o próprio "inconsciente nacional" . Outrossim, o que nos tempos de Gregório de Matos se restringia a uma "dinâmica liberal" converte-se ao fim de dois séculos, com a progressiva ascensăo dos mestiços e a sua crescente hegemonia nos quadros do Exército, em revolta aberta, a "desforra de oprimidos" ou "choque do inconsciente" a que se refere Milkau caracterizando o golpe armado por que se instaurou a República entre nós e a cujos primórdios de jacobinismo florianista parecem se aplicar ambos os rótulos. Tampouco falta, no mulato ou mestiço estereotipado em Canaã, o sensualismo de índole que lhe atribuía Araripe Júnior. Esse traço não só avulta no retrato de Joca, o mulato maranhense por cujos versos perpassa "o frêmito da luxúria meiga e doce de toda a sua raça", como principalmente nas diatribes racistas de Lenz, para quem a civilização no Brasil não passava de um "artifício, todos os minutos rotos pelo sensualismo, pela bestialidade e pelo servilismo inato do negro" (13). Note-se aliás, de passagem, que os dois protagonistas alemáes de Canañ, por sua castidade de conduta e de pensamento, mais parecem encarnaçōes do Parsifal wagneriano. Milkau se sente " humilhado, confuso, arrependido" por certa noite ter desejado Maria carnalmente, e quando consegue dominar a "sua agonia sexual", tem-se por um altivo e virtuoso "vencedor de si mesmo". Entretanto, na antevisão que o panorama de Porto do $\mathrm{Ca}^{-}$ choeiro lhe suscita logo depois de ali chegado, discerne ele a "pérfida lascívia" com que a gente morena da terra combate a "temerosa energia"dos imigrantes louros como uma força positiva para a criaçáo da "nova raça que seria a incógnita feliz do amor de todas as outras, que repovoaria o mundo e sobre a qual se fundaria a cidade aberta e universal" da utopia fraterno-solar sonhada por ele como a Canaã moderna.

Acerca desta última citação, impóem-se duas observações fundamentais. A primeira diz respeito à composiçăo étnica dessa raça futura, que, embora se vá constituir sobre o "mesmo fundo de populaçáo mestiça" do passado e do presente do País, assinalará a "idade dos novos brancos, vindos da recente invasão" substituindo-se à "época dos mulatos", aos quais só restará o consolo de os substitutos reconhecerem "o patrimônio dos seus predecessores mestiços, que terão edificado alguma coisa, porque nada passa inutilmente na terra" (14). Eisnos assim de volta à estratégia do embranquecimento progressivo que vimos coroar a teoria racial de Sílvio Romero. Ela seria retomada por Oliveira Viana, em cuja tese do branqueamento ou "evolução ariani- 
zante" da população brasileira Guerreiro Ramos vê "uma racionalizaçăo do preconceito de cor vigente em nosso país", uma ideologia na qual "se contém, de maneira muito sutil, a discriminação de cor". Racionalização do mesmo tipo subjaz às contradições facilmente detectáveis no pensamento racial de Canaã, onde posiçóes "progressistas" - a refutaçáo da idéia de superioridade de raça e a defesa do sincretismo e da mestiçagem como formas de incorporação do imigrante à tradição da cultura brasileira - convivem com estereótipos ideológicos, a exemplo da visão pejorativa do ascenso social do mulato, que se torna assim uma espécie de bode expiatório das mazelas da primeira República, cuja crítica em Canã̃ antecipa a do reformismo tenentista dos anos 20. Com isso se configura uma ambígua alternância de otimismo (Milkau) e de pessimismo (Maciel) quanto aos destinos vindouros do Brasil como nação, alternância que se faz também sentir no ideário do Modernismo de 22-28, conforme logo se verá.

A segunda observação que se impóe fazer sobre a utopia racial sonhada por Milkau tem a ver com o qualificativo "fraterno-solar" por que o caracterizamos. O fraterno, no caso, corre por conta do anarquismo cristão de Tolstói onde, ao que tudo indica, Graça Aranha teria ido buscar as idéias sociais que veicula pela boca de Milkau: este tem o espírito voltado o tempo todo para um vago coletivismo a que se chegaria, em futuro indeterminado, pela via incruenta do aumento de solidariedade entre os homens e náo pela violência da luta de classes. Quanto ao adjetivo "solar", aponta precipuamente para o espaço tropical em que ele espera ver um dia erguida a sua "cidade aberta e universal". É um espaço que, pela sua exuberância de vida, se contrapóe ao clima temperado da Europa, locus da decadência para Milkau. Daí a recorrência do sol como fulcro da paisagem fortemente semantizada de $\mathrm{Ca}$. nãa. Ao influxo dele está ligada, por um nexo de causalidade que na sua teoria do estilo tropical Araripe Júnior cuidou de acentuar, tanto a tez escura da populaçáo mestiça quanto a sensualidade que lhe é inata. Não estranha pois que o racista Lenz se queixe do "sol implacável" (15) com o seu "amarelo a nos perseguir", nem que tenha por impossível a subsistência da civilização num país onde a "violência" e a "exuberância" da natureza se constituem num "imenso embaraço". Em pólo oposto, Milkau se embriaga com a vitalidade e luminosidade dos trópicos, tanto assim que, quando chega a Porto do Cachoeiro, desapontase com o aspecto demasiadamente ordeiro da cidade. A "branca aridez" de suas ruas que nenhuma árvore sombreia, e a "esterilidade rigorosa $\mathrm{e}$ sistemática" de suas casas sem jardim nem quintal, avessas aos "prazeres do convívio dos animais domésticos" e à "expansiva preocupaçáo da cultura das plantas e das flores", põem de manifesto que só podem 


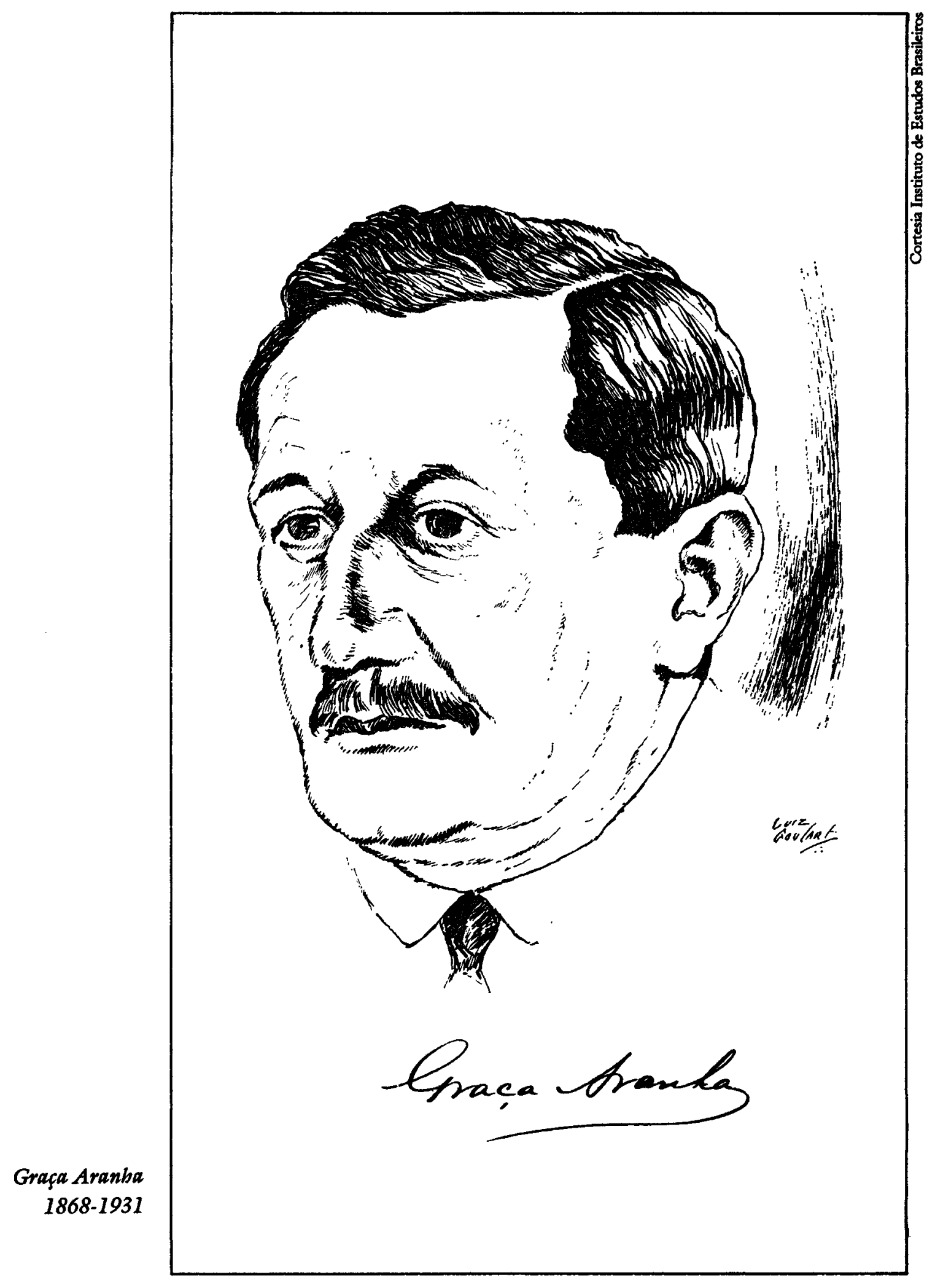


mesmo servir de abrigo a uma população de comerciantes cujo pragmatismo grosseiro "tinha matado a poesia, a graça daquele canto excepcional da natureza".

Se relacionarmos este sentimento de incongruência entre construção artificial e espaço natural à antevisáo de uma nova cultura, prolongando, modernidade adentro, o "toque divino da fusăo criadora" pela qual desde os seus primórdios se pautou sincreticamente a formaçáo da nacionalidade brasileira, a correlaçáo aponta claramente para o ideal de uma civilização tropical em que os avanços materiais e/ou culturais recebidos de fora, em vez de serem mero transplante, passem por um processo de assimilação transfiguradora que lhes dilua ou apague a marca de origem. Deste prisma, o utopismo de Canañ não está muito distante do da Antropofagia, com a sua estratégia de devoraçăo cultural e o seu sonho de uma Revoluçáo Caraíba. Tem igualmente mais de um ponto de contacto com as idéias subjacentes a dois episódios de $\mathrm{Macu-}$ naima, cujo significado alegórico Mário de Andrade explicitaria muitos anos depois da primeira publicação de sua rapsódia num artigo de imprensa(17). Um dos episódios consta no capítulo VIII: Macunaíma se engraça com uma portuguesa vendedora de peixe e vai-se com ela, abandonando uma das filhas de Vei com quem prometera casar-se. $O$ outro episódio aparece no capítulo final do livro: depois de hesitar um bom tempo de medo de água fria, o herói acaba se atirando aos braços da uiara da lagoa que buscava seduzi-lo; quando sai de dentro da água, percebe que está todo mutilado, sem a perna direita, os dedóes do pé, as orelhas, o nariz e os "cocos-da-Bahia". No artigo em que esclarece a alegoria, Mário de Andrade diz que ambos os episódios estão ligados ao "problema de formarmos, de querermos formar uma cultura e civilização de base cristáo-portuguesa" nos trópicos. A Vei do primeiro episódio é a representaçáo mitológica do Sol e quando, em vez de se unir a uma das suas filhas solares, Macunaíma - e o Brasil por ele simbolizado - se amanceba com a vendedora de peixe, está na realidade se jungindo ao "Portugal que nos herdou os princípios cristãos". O episódio subseqüente tematiza a desforra de Vei: é ela quem "faz aparecer a uiara que destroça Macunaíma", destruiçáo em que se configura uma "vingança da quente região solar"; por não ter desposado a filha de Vei, preferindo uma estrangeira, "Macunaíma não se realiza, não consegue adquirir um caráter". Outrossim, na cena da uiara sedutora, o medo do frio que faz o herói hesitar em entrar na lagoa é explicado como o de quem se "arreceia de uma civilizaçáo, de uma cultura de clima moderado europeu". Donde a sedutora mandada por Vei ser uma "uiaradona-Sancha", isto é, européia. Vei "europeíza o seu instrumento de vingança" a fim de atrair Macunaíma, pois não fosse "o europeísmo a 
que se acostumou" durante o seu longo desfrute dos luxos civilizados de São Paulo e ele náo se deixaria enganar.

Conforme mostra Telê Porto Ancona Lopes, em seu fundamental estudo do pensamento de Mário de Andrade, a adesão dele ao "tropicalismo brasileiro" desde 1926, antes do Manifesto antropofágico portanto, se deu sob o influxo das idéias de Hermann de Keyserling acerca da cultura do futuro, da valorização do primitivo e do predomínio dos valores intuitivos sobre os racionais na psique do homem americano. Ao prefaciar o seu até agora impublicado $\mathrm{Na}$ pancada do ganzá, Mário faz o elogio do caboclo ou caipira brasileiro em termos que lembram os de Euclides da Cunha em relaçáo ao sertanejo, ou seja, como modelo de "uma adaptaçáo físico-química à geografia", e acrescenta, significativamente: "Talvez nosso maior erro seja a fatalidade de importar uma civilização européia, que não se adaptará absolutamente ao nosso local, civilização primordialmente anticlimática. Quando, mesmo que aproveitemos da civilizaçáo européia algumas das suas verdades práticas, $O$ que tínhamos e talvez tenhamos de fazer é criar uma civilização menos orientada pelo nosso homem que pela nossa geografia. Uma civilização que sem ser indiana, chim (dar exemplo de civilização negro-africana), egípcia, ou incaica, se orientaria pelas linhas matrizes destas civilizaçóes antigas, ou pseudo-antigas" (18). A propósito, convém lembrar que a filha de Vei a quem Macunaíma promete casamento é, segundo explica o próprio Mário no artigo supracitado, "uma das filhas dá luz, isto é, as grandes civilizaçôes tropicais, China, Índia, Peru, México, Egito, filhas do calor".

Um outro episódio alegórico de Macunaima tem, também, relevância para a ordem de idéias que ora nos ocupa. Trata-se do episódio do banho na água encantada de uma lapa do Araguaia onde Sumé deixara impressa a marca do seu pé. Esse banho, narrado no começo do capítulo V, logra tornar Macunaíma, que nascera preto porque era "filho da tribo retinta dos Tapanhumas", branco, louro e de olho azul, ao passo que seu mano Jiguê, por lavar-se na água já suja da negrice do herói, só consegue ficar "cor do bronze novo", e Maanape, para quem sobrou apenas um restinho de água, continua negro, a não ser nas palmas das mãos e dos pés, que ainda pôde molhar. A exegese corrente é a de ser o episódio uma representaçáo etiológica do surgimento das três raças formadoras da nossa etnia. Todavia, não se deve perder de vista que o poder mágico da água advinha do seu contacto com Sumé, o mítico civilizador branco que, com diferentes nomes, aparece nas mitologias da América como o mestre de quem seus naturais receberam as técnicas, as artes e as regras morais(19). Civilizador que Frei Vicente do Salvador identificou com o "bem-aventurado apóstolo $S$. Tomé" que, 
de passagem pelo Brasil a caminho da Índia, teria ensinado nossos índios a adorar e servir a Deus e não ao demônio. É nessa função que o evoca o texto de Macunaima: a marca do pé dele vinha "do tempo em que andava pregando o evangelho de Jesus à indiada brasileira".

Ora, se o próprio Mário pretendeu alegorizar no episódio do enrabichamento do seu herói sem nenhum caráter pela portuguesa vendedora de peixe nossa submissão ao "Portugal que nos herdou os princípios cristãos", não seria o caso de, com mais fundadas razões, ver-se igual sentido alegórico no episódio do banho encantado, com o que a traição de Macunaíma às suas raízes tropicais receberia um reforço prévio? E mais: não é ainda de se pensar que no dito episódio está simbolizada a compulsão de embranquecimento do mestiço brasileiro a que as doutrinas raciais de Sílvio Romero, Graça Aranha, Oliveira Viana e outros intentaram dar respaldo teórico? A ser assim, o simbolismo só confirmaria a continuidade, no ideário do Modernismo de 22-28, do mesmo horizonte racial de referência que deparamos nos pensadores da geração de 70.

A vinculação entre a "êugenia" racial do Brasil $e$ as novas correntes migratórias que a ele afluíram em número crescente após a Abolição repercute inclusive nos contos de Antônio de Alcântara Machado reunidos em Brás, Bexiga e Barra Funda, protagonizados todos por imigrantes italianos da Paulicéia e descendentes seus. O pitoresco dos costumes, do linguajar, das ambiçôes e dos valores desse microcosmo ítalopaulista é surpreendido pelo contista num traço caricaturesco que não exclui a simpatia ou sequer o enternecimento. Mas nem sempre se pode dizer que tal ótica preponderasse na literatura modernista. Em Macu. naima, por exemplo, o ogre ameríndio que se apodera da preciosa muiraquitã, penhor da nacionalidade do "herói de nossa gente", é significativamente o italiano Venceslau Pietro Pietra, a quem cabe o papel de vilão da narrativa. Nada tem tampouco de lisonjeira a representação ficcional do imigrante nas Memórias sentimentais de João Miramar. $\mathrm{O}$ ítalo-paulista Chelinini, colega de escola do protagonista, pintado com o traço grosso da irrisão, não passa de um carreirista e de um escroque; por sua vez, os agiotas táo detestados quanto procurados por Miramar são todos italianos e "turcos".

No prefácio de Brás, Bexiga e Barra Funda, Alcântara Machado nos dá conta das razóes da sua simpatia pelos "novos mamalucos", que assim chama os ítalo-brasileiros: eles representavam a melhoria do processo de miscigenação das " três raças tristes" que nos formaram, já que nele introduzem um novo ingrediente, particularmente caro aos modernistas: a alegria(20). Outrossim, ao registrar em Cavaquinbo \& saxofone 
suas impressōes de viagem à Argentina, faz ele um elogio da eugenia racial quando intitula seu texto "Onde o homem o é" e quando assinala que lá o "branco não quer se tisnar de negro nem de amarelo e repele, com indisfarçável repugnância, convencido da sua superioridade, a parte negra e mulata da população brasileira. (...) Com sangue europeu do sul, do norte, inclusive judeu, aqui se está formando uma raça de ombros largos, estatura alta, saudável, sólida, igualmente feita para o trabalho e os prazeres da vida" (21).

O viés étnico costuma estar sempre ligado, direta ou indiretamente, às tentativas de definição de um caráter nacional brasileiro. Indicações esparsas nesse sentido náo deixam de aparecer em Canaã, ora compondo o estereótipo do homem cordial - é o caso de Felicíssimo, o agrimensor, e de Joca, seu auxiliar, nos quais Milkau admira "a espontaneidade da raça, a coragem e a bondade" - ora sublinhando traços menos positivos, como o gosto da vadiagem, a luxúria de índole e a falta de aplicaçáo ao trabalho, notados por Paulo Maciel ao contrastar a ordem, o asseio e o progresso da colônia alemá de Porto do Cachoeiro com o desleixo, o abandono, a tristeza das "terras cultivadas por brasileiros" (22). Fiel, nisto, ao contraponto que informa a estrutura toda de Canaã, do estilo à efabulação, tal alternância de notas de encarecimento extrínseco (Milkau) e notas de crítica intrínseca (Maciel) prenuncia a ambivalência entre pessimismo crítico e otimismo utópico que marca a atitude do Modernismo de 22-28 frente à realidade nacional. É possivelmente em Retrato do Brasil (1928), de Paulo Prado, que a dita ambivalência encontra sua formulação mais nítida. Ao traçar o perfil do caráter brasileiro numa perspectiva de psicologia social lastreada de erudição histórica, Paulo Prado ressalta feições que não haviam escapado à atenção do romancista de Canaã. À semelhança deste, hartmanniano para quem o comportamento coletivo tal como historicamente testemunhado afunda raízes num "inconsciente nacional", também aquele, para traçar, mais do que o retrato, a radiografia do Brasil, vai procurar " no fundo misterioso das forças conscientes ou instintivas, as influências que dominaram, no correr dos tempos, os indivíduos e a coletividade" (23). Dessa prospecção histórico-psicanalítica, Paulo Prado traz à tona, como pulsóes de base da psicologia da descoberta e da própria formação nacional, o binômio ouro-sexo, vale dizer, a ambição de riquezas que moveu a Europa à conquista da América e, sobretudo, a "sensualidade livre e infrene" que o colonizador veio aqui satisfazer na índia e na negra, conquanto, para o ensaísta, o negro se fosse constituir no "problema mais angustioso" da nossa "formação racial". Conforme tivemos ocasião de ver, o suposto "sensualismo" e "bestialidade" do negro brasileiro eram, no entender de Lenz, um impedimento para a 
civilizaçăo, e mesmo Milkau, embora a tivesse por positiva, não deixava de sublinhar a "pérfida lascívia" da raça mestiça. Num outro passo de Retrato do Brasil, seu autor chama a atenção para a "falta de proporção" entre o homem e a floresta tropical, que "abafa, sufoca e asfixia o invasor"; mais adiante, mostra os povoadores das vastidóes do território brasileiro "abafados e paralisados em geral por uma natureza estonteadora de pujança, ou terrivelmente implacável". Ora, a vitalidade e exuberância da natureza tropical são semantizadas, na escrita caracteristicamente art nouveau do romance de Graça Aranha, como valores simbólico-ornamentais que subscrevem a utopia social do Novo Mundo sonhada pelo seu protagonista, um egresso da decadência e do esgotamento vital do Velho Mundo. Para Milkau, "a floresta do Brasil é sombria e trágica" e ele sente ali o seu espírito "esmagado pela estupenda majestade da natureza"; mais pragmaticamente, a "terra só por si, com esta violência, esta exuberância" oferece, para Lenz, um "embaraço imenso" no que toca à marcha da civilização no País.

Mas a principal plataforma de encontro entre as idéias - talvez se devesse dizer ideologias - de Canañ e Retrato do Brasil é a questão da mestiçagem. Elą se confunde com a da própria identidade nacional, e um e outro livro a consideram um processo ainda em curso a que, numa impressiva similitude de linguagem, atribuem duração cósmica e cujo termo lhes é por enquanto uma incógnita. Mostrando que no final da década de 20 o horizonte racial continuava a ser a barreira não-ultrapassada das cogitaçōes em torno da realidade brasileira, Paulo Prado não se pejava de ver na miscigenação um tríplice problema, o "da biologia, o da etnologia e mesmo o da eugenia" [grifo meu] (24). Embora perfilhe a tese de uma democracia racial brasileira, onde o "negro náo é um inimigo: viveu, e vive, em completa intimidade com os brancos e os mestiços que já parecem brancos"; embora rejeite a tese da desigualdade de raças, que lhe "parecem essencialmente iguais em capacidade mental e adaptaçăo à civilização", tem todavia o mulato como "o ponto mais sensível do caso brasileiro", do mesmo passo em que reputa "a arianizaçáo do habitante do Brasil (...) um fato de observaçáo diária", ligado de perto "às imigraçóes européias de vário sangue que deveráo ter profunda influência no Brasileiro futuro".

Entre os estigmas deixados pela escravidão "nas profundezas inconfessáveis do caráter nacional", vários dos apontados por Paulo Prado - a preguiça, o desleixo, a imprevidência, para não falar da tristeza, traços que nos teriam vindo já dos descobridores portugueses - são os mesmos que Canañ aponta sem se esquecer de os vincular a uma circunstância histórica, às "terras cultivadas por brasileiros" na época da 
decadência da propriedade tradicional por força da abolição do trabalho escravo. Para o ensaísta de Retrato do Brasil, ainda não culminaram os "efeitos da recíproca penetração biológica" que iráo definir "o novo tipo étnico que será o habitante do Brasil". E ele se pergunta "que influência pode ter no futuro essa mistura de raças", acrescentando a esta uma segunda pergunta, anacrônica numa altura em que a medicina já havia negado nexos necessários de causalidade entre mestiçagem e enfermidade: a de se "a fraqueza física" de grande parte de nossa população, e sua vulnerabilidade "às doenças e aos vícios (...) não provém do intenso cruzamento de raças e sub-raças". Mas não se arrisca, no post-scriptum do seu livro polêmico,a responder tais perguntas embaraçosas, preferindo antes esperar, "na lentidáo do processo cósmico, a decifração do enigma" ou "incógnita".

O utopismo do romancista pré-moderno de Canaa que, levado pelos pendores filosóficos da Escola do Recífte, deu amplitude cósmica ao problema da imigraçáo estrangeira e do seu impacto sobre os destinos da civilizaçáo brasileira, foi bem mais afoito do que o ceticismo do ensaísta modernista de Retrato do Brasil. Se bem Graça Aranha falasse, também, de "incógnita", abrandou a ambigüidade ominosa desse substantivo com o adjetivo "feliz" e pôde discernir, no horizonte antecipatório do pré-modernismo, "uma nova raça, que seria a incógnita feliz do amor de todas as outras, que repovoaria o mundo e sobre a qual se fundaria a cidade aberta e universal".

\section{Notas}

1 Citaçōes da História da literatura brasileira, $5^{2}$ ed. org. por Nelson Romero, Rio, J. Olímpio, 1954, v. V, p. 1666 e v. I, p. 335-336.

2 Os sertoes ed. preparada por Alfredo Bosi e Herstlio Ângelo, Săo Paulo, Cultrix, 1973, pp. 98-99 e 29.

2b Segundo Thomas E. Skidmore - cujo Preto no branco, raça e nacionalidade no pensamento brasileiro (Rio, Paz e Terra, 1976), te att agora o estudo mais completo acerca das idéias raciais no Brasil - cabe a Capistrano de Abreu, com os seus Caphrulos de histria colonial (1907), a primazia da substituiçăo do " conceito de raça pelo de cultura, refletindo assim a mudança no pensamento antropológico que triunfou nos Estados Unidos e na Europa entre 1900 e 1930" (ob. cit., p. 120). Nisso, Capistrano foi secundado de perto por Alberto Torres, que ao criticar o racismo no Brasil "endossava a escola culnuralista de pensamento que estava entăo (na década imediatamente anterior à Primeira Grande Guerra) emergindo sob a liderança de Franz Boas, da Columbia University" (idem, p. 136).

3 Até o fim deste parágrafo, as citaçōes de Canaa, feitas pelo texto da $5^{2}$ ed. rev., Rio, Garnier, (1913), são respectivamente das p. 113, 42, 271 e 50. Năo obstante suas opinióes agressivas, Lenz é apresentado como um idealista do mesmo estofo de Milkau, que o estimava e compreendia, conforme dá a entender nesta avaliaçăo dele: " O.caráter fraco (de Lenz) traía a audácia do sonhador, e a bondade do sentimento entorpecia-lhe 
as maldades grandiosas do seu idealismo" (p. 143). Nesse sentido, tanto Milkau quanto Lenz tipificam, em contraposiçāo ao esteré́tipo do homem-da-vida apontado por Mário de Andrade como o lado pragmático do caráter alemão, o seu antípoda, o homemdo-sonho "trapalhăo, obscuro, nostalgicamente filósofo, religioso, idealista incorrigível, muito sério" (Amar, verbo intransitivo, São Paulo, Martins, 1944, pp. 25-26). Esta tipificaçăa, que se diria inspirada nos dois protagonistas de Canañ, fora de resto antecipada pelo próprio Graça Aranha num trecho do romance (ed. cir., pp. 23-24) em que, glosando o tema goethiano das duas almas fáusticas alemãs, contrasta o " gênio livre" da "pátria do individualismo" com a "obediência e tenacidade" do seu "caráter camponês e militar".

4 Historia da literatura brasileira, ed. cit., v. I, p. 335.

5 José Veríssimo, Estudos de literatura brasileira, 5ª série, Rio, Garnier, 1905, p. 27.

6 Até o fím do parágrafo, citaçōes de Canañ, ed. cit., pp. 322, 324, 325, 326, 329 e 330, respectivamente.

7 Citaçōes deste parágrafo ainda de Canaã, ed. cit., pp. 48 e 49.

8 A respeito, consultar, de Roberto Ventura e Flora Süssekind, Historia e dependencia, cultura e sociedade em Manuel Bonfim, São Paulo, Moderna, 1984, que se propōe a resgatar do esquecimento o pensamento de Manuel Bonfim.

9 Frases de Raul Bopp em Movimentos modernistas no Brasil (1922-1928), Rio, Liv. S. José, 1966, pp. 97 e 64.

10 Graça Aranha, Espirito moderno, São Paulo, Ed. Nacional, s. d., 2ª ed., pp. 85-102.

11 Araripe Júnior, Obra critica, v. II (1888-1894 pp. 68-73, "Estilo tropical. A fórmula do naturalismo brasileiro") Rio, Casa de Rui Barbosa, 1960.

12 Ob. cit., p. 432.

13 Citaçōes de Canaã até o fim deste parágrafo conforme ed. cit., pp. 136, 50, 264, 31 e 112.

14 Canaã, ed. cit., p. 331.

15 Guerreiro Ramos, Introdugấo critica d̀ sociologia brasileira, Rio, Andes, 1957, p. 140.

16 Até o fim do parágrafo, citaçóes de Canaâed. cit., pp. 37, 48 e 27.

17 Oartigo, intitulado Notas didrias e originariamente publicado em 1943, no quinzenário

"Mensagem", de Belo Horizonte, vem transcrito na ediçăo crítica de Macunaima feita por Telê Porto Ancona Lopez (São Paulo, Rio, LTC/Sec. da Cultura, Ciência e Tecnologia de SP, 1978, pp. 325-326).

18 Apud Telê Porto Ancona Lopez, Mário de Andrade: ramais e caminho, São Paulo, Duas Cidades, 1972, pp. 111-118.

19 Ver o verbete "Sumé" em Luís da Câmara Cascudo, Dicionário do folclore brasileiro, Rio, INL, 1954, e Hernâni Donato, Dicionário das mitologias americanas, São Paulo, Cultrix/MEC, 1973.

20 Cf. Brás, Bexiga e Barra Funda/Laranja da China, São Paulo, Martins, s.d.

21 Capaquinbo e saxofone (solos), 1926-1935, Rio, J. Olímpio, 1940, p. 187

22 Canat, ed. cit., pp. 277 e 209.

23 Paulo Prado, Retrato do Brasil, São Paulo, Brasiliense, 5ª ed., 1944, p. 161. Parece ter havido aqui um lapso de revisăo no original; onde se lê " conscienres", dever-se-ia ler "inconscientes" possivelmente. As demais citaçōes do parágrafo são das pp. 11, 163, 17 e 175-176. 
24 As citaçóes da mesma obra, neste e no parágrafo seguinte, são das pp. 166, 167, 171, 170,162 e 169.

\title{
Resumo
}

O artigo se propóe analisar as idéias expressas pelos principais personagens de Canat, de Graça Aranha, em torno dos vínculos entre raça e cultura, do processo de mestiçagem e do futuro embranquecimento da populaçăo brasileira numa utopia fraterno-solar. Essas idéias săo correlacionadas, de um lado, às preocupaçōes de Silvio Romero, Euclides da Cunha e Araripe Junior com a adequaçăo entre meio geográfico, raça e cultura, e, de outro lado, ao empenho do modernismo paulista em definir um caráter nacional brasileiro. Empenho discernível, no nivel da representaçáo simbólica, em Macunatma e, no da teorizaçäo mais sistemática, em Retrato do Brasil, que chega a falar de eugenia ao discutir o futuro tipo étnico brasileiro.

\begin{abstract}
The article purports to examine the ideas which the main characters of Canan, by Graça Aranha, express on the relations between race and culture, as well as on the racial melting process and the future whitening of the population of Brazil in a brotherly and solar Utopia. These ideas are correlated, on one side, to the concern of Silvio Romero, Eudides da Cunha and Araripe Jr. with the adequation between geography, race and culture; on the other side, to the concern of S. Paulo's Modernist movement to define a Brazilian national character. This concern can be seen, on the level of symbolical representation, in Macunatma and, on the level of a more systematic theorizing, in Portrait of Brazil, which goes so far as to mention eugenics when discussing the future Brazilian ethnical type.
\end{abstract}

José Paulo Paes é poeta, ensaísta e crítico literário.

Este texto é parte de um ensaio sobre Canaã e o ideário modernista, feito com bolsa da Ford Foundation através do IEA, a ser proximamente publicado em livro pela Editora da USP. 